\title{
The Implementation Strategy of Student - Centered University Class
}

\author{
Hui Xu \\ School of Computer Sci. \& Tech \\ Nantong University, Nantong \\ Nantong, 226019, China \\ xu.h@ntu.edu.cn
}

\author{
Rong-xiang Guo* \\ Office of Academic Affairs \\ Nantong University \\ Nantong, 226019, China \\ *Corresponding author: guo.rx@ntu.edu.cn
}

\begin{abstract}
The "teacher-centered" classroom teaching model results in poor teaching and learning, inadequate teaching content in depth and breadth, and a single teaching method and pattern. Therefore, this paper discusses the "student-centered" classroom teaching principles and classroom instructional design. The principles include: promoting students' all-round development, giving full play to the role of students, conducting a diversified evaluation, and providing students with a full range of services; In teaching design, teachers and students must work together to build a new teaching environment and enhance students' active learning awareness and ability. Teachers should attach the importance of the guidance, understanding and thinking of knowledge discovery, and adopt diversified teaching methods for different teaching goals. Only by gradually changing the center of classroom teaching from teachers to students can we get rid of the predicament of classroom teaching.
\end{abstract}

Keywords-Student-centered; University class; Principle; Instructional design

\section{INTRODUCTION}

Since the Middle Ages, universities have been the institutions that teach and learn advanced science. However, due to the limitation of media and channels, the people who master these profound knowledges are very few. With the rise of the information technology revolution, electronic information has replaced paper information, and the digital media has dramatically expanded the scope of knowledge dissemination and broadened the channel of knowledge dissemination [1]. More and more people have access to profound knowledge, and knowledge is instantly transmitted, infinitely copied and low cost, and the traditional teaching organization model of the university has been affected.

As the main carrier of education and the main position of university teaching reform, university classroom has no doubt about the value and significance of talent training quality. The modern university classroom is not only a place to disseminate knowledge, but also a "laboratory" to cultivate students' dialectical thinking and solve practical problems. Teachers should keep an open mind and take effective measures to share the dominant position of the classroom with students, improve students' classroom performance, and effectively improve the quality of university classroom and personnel training.

\section{THE MAINSTREAM MODEL OF UNIVERSITY CLASSROOM}

\section{A. Two Models}

Generally speaking, the current Chinese university classroom still belongs to the traditional model of teachercentered, that is, teachers teaches in classroom with PPT presentation around teaching objectives and content, evaluate students' classroom knowledge in the form of examination papers and graduation theses. The students did not take notes in class and are exceptionally silent. Teachers have first-rate scientific research and academic standards, but not in the classroom to stimulate students to explore the interest of knowledge.

Teacher-centered and student-centered represent two completely different values. The two concepts are essentially different from each other in their understanding of the nature of the university and the purpose, methods and evaluation of the university. These two completely different paradigms, the former affected the past college teaching, the latter is affecting current university teaching. At the Ninth Ministerial Meeting of the European Higher Education Area in June 2015, more than 47 members of the Bologna Process and more than 500 representatives from UNESCO, the World Bank, the OECD, the European Union and other institutions unanimously adopted the "Yerevan Bulletin", it clearly states: "Encourage and support institutions of higher education and teaching personnel to carry out education and teaching innovation and form a 'student-centered learning environment, strive to cultivate students' creativity, innovative spirit and entrepreneurial ability [2]."

Ubiquitous and freely available information breaks the monopoly of knowledge and information by universities and teachers, leading to the university crisis. The role of traditional university teachers is being replaced, and the core values of university teaching also virtually change. Universities are not only institutions for the provision of education, but also institutions for the production of knowledge. Teaching content is no longer confined to books, but more attention to new knowledge and practice. Teaching is no longer taught by teachers and accepted by students. Instead, teachers and students form a new learning union, producing new knowledge 
and discovering new laws. Universities are responding to the society in a new form.

\section{B. Comparison of the Two Models}

The idea of "student-centered" first proposed by American psychologist Carl. Rogers. The initial idea is to let students to determine the learning objectives, and to measure the degree of progress through self-assessment, thus students are selfresponsible learners [3]. In fact, the comparison between the mode of teaching and the way of learning is the comparison between teacher-centered and student-centered. The most important difference between the two is reflected in four aspects: teaching investment, teaching task, teaching process and evaluation method.

1) Teaching investment. Teacher-centered teaching, appropriation and allocation of resources are based on teaching needs, focusing on the quantity and quality of teaching resources such as teachers, teaching materials and teaching facilities. Student-centered teaching, pay more attention to the quantity and quality of students' knowledge and skills such as learning outcomes, investment is based on learning needs

2) Teaching task. Teacher-centered teaching take subject knowledge as the main teaching content, teachers teach subject knowledge in the classroom and observe whether the student masters the knowledge. Student-centered teaching guides students to find and build their own knowledge, teachers develop students' abilities and talents by creating an efficient learning environment.

3) Teaching process. In teacher-centered teaching, teachers serve as lecturers, impart knowledge bit by bit, teachers say and students listen without disturbing each other, teachers are responsible for the teaching process. In studentcentered teaching, teachers play the role of designers, designing scientifically effective learning environments and processes, collaborating with other departments and colleges in schools to help and guide students in acquiring, building, creating knowledge and teachers being responsible for teaching outcomes.

4) Evaluation method. In teacher-centered teaching, the teacher often assesses the student after the course is over and the student can earn a degree as soon as the required credit is completed. The student-centered teaching requires teachers to continuously evaluate students. Different internal and external evaluation methods are used before class, in class and after class to let students know their own knowledge and abilities. The degree is linked to the knowledge and skills acquired by students.

It can be said that the central position of students in running a university has become a consensus in the field of international higher education. The teaching paradigm is forming starting from students' needs, students' development and students' ability, that is also the point, goal and focus. Under the background that the quality of higher education changes, the cost of education is shared by students, the theory of human capital is prosperous, and the humanistic value of learning society is established, people have more value appeals to the "student-centered" teaching philosophy and method.

\section{STUdENT-CENTERED COLLEGE ClASSROOM}

\section{A. The Realization Principle of Student - centered University Classrooms}

The student-centered college classroom must be aimed at promoting students' growth and success, Change the status quo that students don't want to learn, passively learn and don't learn, enhance students' study of the subjectivity, initiative and creativity, change teachers' "one-word classroom" classroom teaching mode, enhance the teacher's leading, educational and artistic, strengthen the overall quality of students and ability training, improve the Quality of Talents Cultivation in Higher Education in an All - round Way.. To this end, the implementation of student - centered classroom teaching should follow the following principles [4].

1) Classroom should promote the all-round development of students. Student-centered teaching should be the ultimate goal of promoting students' growth, Fully consider the development needs of the society and the industry, develop the learner-centered curriculum combining with the advantages of the discipline of the school, and construct a flexible curriculum system and personnel training program so as to guide and promote the all-round development of the students.

2) Classroom should play the main role of students. Student-centered teaching should actively create a learning environment that supports and grows with each other, and guide students to build their own knowledge and experiences through self-development to continuously create new knowledge and experiences. Students are encouraged to participate in teaching and learning autonomy and introspection so that students Mastering subject knowledge and skills while thinking independently, using creative thinking to adapt to the environment and practice.

3) The course evaluation should be diversified. The student-centered teaching evaluation should focus on the evaluation of teaching quality from the teacher's teaching effect to the student's learning outcomes, develop a clear score and evaluation criteria, take a variety of forms to examine the level and ability of students to master and apply knowledge through various channels. The evaluation system can break the previous model of teachers as a single main body of evaluation, adding students' self-assessment, peer assessment and external evaluation of other sectors. The diversity of evaluation makes the evaluation results more objective, more comprehensive and more fair.

4) The school should provide all-round service for students. Establish a "student-centered" education support environment, optimize the hardware resources allocation for all kinds of teacher-student learning and research, cultivate a quality awareness and culture with the school's own characteristics, and improve training programs and management systems that are suitable for the talent training objectives. build a student learning support service system, consultation and feedback service system, and a subsidy service system to provide students with quality learning services and improve student acceptance and satisfaction. 
The student-centered teaching philosophy means that the teaching purpose and process take the students' learning and development as the core, realize the transformation of center from "teaching" to "learning", from "teaching mode" to "learning mode". Teaching methods and content changes from "teaching" to "guide", from "textbook" to "new knowledge". The training effect and evaluation aim at improving the learning effect and student's quality, from focusing on "how to teach" to "how to learn", from "teaching well" to "getting good at learning", focusing on "teaching effect satisfaction" to learning effect satisfaction ".

\section{B. Teaching Design of Student-centered University Classrooms}

Bloom, a famous psychologist and educator in the United States, proposed six levels of cognition: memory, understanding, application, analysis, synthesis and evaluation [5]. Among them, memory and understanding belong to "lower order learning", application, analysis, synthesis, evaluation belong to "higher learning", higher learning is more conducive to cultivating people's thinking ability and creativity. The undergraduate education paradigm is suitable for low-order learning. Student-centered learning paradigm is more suitable for higher learning, is conducive to cultivating students' ability to think critically, solve complex problems and creation [6]. The student-centered teaching design includes several aspects such as teaching purpose, teaching content, teaching methods and teaching mode.

1) High-level learning ability as the main training objectives. The traditional classroom with basic knowledge as the main teaching content should be changed. Teachers have higher requirements for students' learning, arrange for students to read and understand teaching materials and related materials before class. The classroom is focused on knowledge application and problem analysis, carry out peer study and teaching, create a learning environment for students to actively learn. Students' ability to solve practical problems and critical thinking ability is enhanced by participating in a series of activities of the team.

2) A new learning environment jointly built by teachers and students. In the classroom, students are the main body of information processing, is the active constructor of the meaning of knowledge. Teachers are the organizers and advisors of teaching. They are the helpers and promoters of the students 'self-constructing meaning. They organize class discussions, stimulate students' thinking, understand the progress of learning, and Interact with and encourage students.

3) Students' active learning consciousness and ability enhance by making full use of various types of teaching media and learning resources. Teaching media and various resources are cognitive tools and collaborative communication tools to promote students' autonomous learning. Teaching materials are not the only source of knowledge for students, and students can learn knowledge from a variety of learning objects and teaching resources. Teaching media no longer only assist teachers to teach, but to focus on helping students learn. Students are more motivated, their sources of knowledge are richer, their knowledge is updated faster and more in line with reality.

4) The guidance, understanding and thinking of knowledge discovery are emphasized. Teachers who hold teachercentered teaching philosophy promptly inform students of knowledge rules, whereas teachers who hold student-centered teaching concepts introduce the discovery process of knowledge rules to students. Teachers must devote more time and energy to engaging in productive and creative activities as those who help discover the contradictions rather than reveal the truth.

5) Multi-teaching method is adopted in combination with different teaching objectives. Establishing a transition between the teaching paradigm and the learning paradigm connects teaching methods such as teaching, paraphrasing, operation and practice, demonstration, discussion, group cooperation, guided exploration, contractual, role playing, planning, inquiry and self-evaluation. According to different teaching objectives and content, we should adopt multiple teaching methods to confirm students' improvement in concept understanding, knowledge application and analysis, ability improvement and so on.

6) Teaching students in accordance with their aptitude Teaching students. Before the beginning of the course teaching, you must know and understand the knowledge and abilities that the students already have. In course teaching, attention should be paid to collecting students' classroom learning information and ensuring that the information is consistent with the learning objectives of the course so that evaluation activities can be coordinated with teaching and learning.

7) Assessment Guided Learning. Establish clear curriculum requirements and assessment methods, and open it to students, so that students fully understand the curriculum requirements and goals. Communicate to students or discuss the task standards with students, so that students can learn to evaluate the quality of their tasks against the standards and help them to perform self-evaluation and peer review. Guaranteed that the curriculum and evaluation plan can take into account students from different levels and backgrounds, providing every student with opportunities and a stage for showing learning outcomes. Assigning assessment tasks to students should consider their challenges to students' intelligence, balance difficulty and breadth, and provide them with certain help and resources for completing their tasks.

In short, taking students as the center requires that universities not only have their own training programs and characteristics, but also consider the needs of students and provide personalized teaching; not only maintain the overall high level of teaching quality, but also pay attention to every student and create an efficient learning environment to help them grow and develop; not only teach traditional knowledge, but also providing the latest knowledge and the most advanced skills; not only enables students to become knowledgeable people, but also cultivates their ability and quality to meet the needs of modern society. To complete this transformation, we need to further establish a student-centered teaching philosophy, clarify student-centered teaching purposes, and conduct elaborate and scientific strategic design of teaching and evaluation 


\section{CONCLUSION}

Teacher-centered teaching and student-centered teaching are not antagonistic and contradictory. Because the process of cognition is regular, students can only create and build new knowledge and skills only after they have acquired the basic knowledge and skills. Therefore, the imparting of knowledge is still an important part of university teaching. Only by combining the two teaching paradigms, it is reasonable to adopt different teaching methods according to different teaching purposes. The teaching reform is a long process. The existing teaching paradigm has formed a complete and relatively solid system structure. It is unrealistic to accomplish the transition and transformation of the two paradigms at once. How to form the most scientific teaching mode so as to improve the learning Needs and deserves our constant exploration and practice.

\section{REFERENCES}

[1] X. Zhu, "Historical review and value orientation of educational philosophy of 'Student-centered'," Modern Education Management, vol, 4, pp. 6-9, 2012. (In Chinese)

[2] YEREVAN COMMUNIQUE, https://www.eurashe.eu/library/modern ising-phe/ EHEA_2015- Yerevan-ommunique.pdf, 2015.

[3] C.X. Yang, X.D Zou, "The Student-Centered inner-university Guarantee of teaching quality: theory construction and strategies toward Improvement," Research in Educational Development, pp.30-44, Mar. 2015. (In Chinese)

[4] F. CHEN, "How to Make Student-centered Teaching Possible," Journal of Higher Education, pp.75-82, Oct. 2017. (In Chinese)

[5] B. BLOOM, "Taxonomy of Educational Objectives Volume I:The Cognitive Domain," New York, McKay, 1956.

[6] G. L. Zhou, R.X. Huang, How to Institutionalize Teaching Reform"Student- centered Learning" education reform and the rise of the SAR of innovative talents cultivation in China, Research in Higher Education of Engineering, pp.47-56, May 2013. (In Chinese) 